\section{Human rights and deinstitutionalization: A success story in the Americas}

Alison A. Hillman ${ }^{1}$

Key words: human rights; deinstitutionalization; mental health; hospitals; psychiatric; Paraguay.

\footnotetext{
1 Director, Americas Advocacy Initiative, Mental Disability Rights International. Send correspondence and reprint requests to: Alison A. Hillman, Americas Advocacy Initiative, Mental Disability Rights International, 1156 15th Street, NW, Suite 1001 Washington, DC, 20005, United States of America; telephone: (202) 296-6551; fax: (202) 7283053; e-mail: ahillman@mdri.org
}

On December 9, 2003, Mental Disability Rights International (MDRI) and the Center for Justice and International Law (CEJIL) filed a petition for precautionary measures-a type of emergency reliefbefore the Inter-American Commission on Human Rights (Commission) to protect the lives and health of 460 individuals detained in Paraguay's state-run Neuro-Psychiatric Hospital. During an October 2003 investigation, MDRI attorneys and volunteers found two teenage boys, Julio and Jorge, detained in 2-by-2-meter isolation cells, naked, without access to bathrooms. Hospital staff said they had been locked in these cells for over four years. While documenting conditions for Julio and Jorge, MDRI investigators discovered that the conditions and treatment of the other 458 individuals detained in the institution differed little from the boys' dehumanizing and abusive circumstances. Accordingly, MDRI and CEJIL attorneys framed their petition to document not only the egregious human rights violations suffered by Julio and Jorge, but the abuses inflicted upon all 460 individuals detained in the Neuro-Psychiatric Hospital.

On December 17, 2003, in a historic decision, the Commission granted MDRI's and CEJIL's (petitioners) request for precautionary measures to protect the lives and physical, mental, and moral integrity of the entire population of 460 detained in Paraguay's state-run Neuro-Psychiatric Hospital. This marked the first time that the Commission acted to call for immediate, life-saving measures to combat ongoing abuses in a psychiatric institution.

The Commission's granting of the precautionary measures, however, was only the first step in this ground-breaking human rights advocacy effort. After 14 months of oversight by the Commission, the Paraguayan government signed a settlement agreement with the petitioners to restructure the country's mental health system. While the precautionary measures were the catalyst that began to bring to an end the horrendous abuses within the psychiatric facility, the settlement created an obligation for the government to provide the social and medical services necessary to integrate people with mental disabilities into the community. Without the threat of further litigation in the inter-American system, these major changes in mental health policy and practice may never have occurred. The Paraguay precedent demonstrates how the interAmerican human rights system can be used to recognize and enforce the rights of people with men- 
tal disabilities. For disability rights activists, this precedent-setting settlement is another step toward international recognition of a right to community integration for people with mental disabilities.

\section{BACKGROUND TO HISTORIC MENTAL DISABILITY RIGHTS ADVOCACY}

\section{Findings from MDRI's Initial Investigation into Abuses in the Neuro-Psychiatric Hospital}

In October 2003, after receiving reports that there were two boys diagnosed with autism locked in tiny cells in Paraguay's Neuro-Psychiatric Hospital, MDRI sent a team to Paraguay to investigate and document the situation. Julio and Jorge were frighteningly thin, locked naked in tiny isolation cells without access to bathrooms. They lived among their own feces and urine in cells that were almost completely bare. Holes in the cell floors designed to be latrines were crammed and caked over with excrement. The cells reeked of urine and feces, and the cell walls were smeared with excrement. Each boy was infested with lice, covered with scars, and spent approximately four hours every other day in an outdoor pen, which was littered with human excrement, garbage, and broken glass (1).

During a two-day investigation, MDRI documented atrocious treatment and conditions for all 460 people detained in the institution, which has a stated capacity of 350. Developmental disabilities experts John J. McGee and Gerald Provencal, accompanied MDRI on this visit and prepared a 60-page report describing the inhuman and degrading treatment and unhygienic conditions in the facility. ${ }^{2}$ Detainees urinated and defecated in public patios, while others knelt to drink from standing pools on the same patios. Showers, sinks, and toilets were nonfunctional and lacked soap and towels. Existing toilets consisted of filthy holes-in-the-floor. Some individuals were compelled to sleep in close proximity to these holes encrusted with excrement. The stench of open sewage and rancid garbage permeated the buildings inside and out (1).

The institution suffered from dangerous levels of staffing, giving rise to near-universal neglect and resulting in actual harm. The low staff-topatient ratio placed more vulnerable patients at risk due to aggression from other patients and selfharm. Available staff were unable to render active

\footnotetext{
Mental Disability Rights International and Center for Justice and International Law, Request for Precautionary Measures to the InterAmerican Commission on Human Rights on Behalf of the Individuals Detained in Paraguay's Neuro-Psychiatric Hospital. Washington, D.C., December 2003.
}

treatment (2). Treatment interactions between staff and patients were largely limited to the distribution of medications from the opposite side of locked bars. Insufficient staffing created the inevitability of locked buildings, the use of isolation cells, and the widespread use of chemical restraint (large doses of sedating medications to render patients docile and listless) (1).

The entire facility was a prison-like setting with almost no recognition of the individuals' mental health needs, and representing little more than sub-custodial warehousing. A large number of patients slept in barred isolation cells, often with padlocked cell doors. There were no written orders or policies for such seclusion. A survey of medical records revealed that little relationship existed between the use of medications and actual psychiatric diagnoses. Only four of 13 patient records surveyed recorded a diagnosis. Medical records were disorganized and lacked diagnostic information, case histories, family contacts, evaluations, treatment and discharge plans, and medication histories.

Concluding the two-day investigation, investigators determined that the hospital represented an immediate health hazard to those who were detained in or employed by the institution. In addition, investigators documented the detention of children side-by-side with adults, in contravention of international standards, and the lack of any viable community-based mental health services (1).

\section{Petitioners File for Precautionary Measures with the Inter-American Commission}

To challenge these abuses, MDRI and CEJIL filed a petition for precautionary measures with the Inter-American Commission on Human Rights (the Commission). Precautionary measures are an instrument within the inter-American human rights system that allows the Commission to promptly address compelling human rights violations based on a determination that a government is inflicting irreparable harm to an individual's rights. Petitioners argued that Paraguay's detention of Julio, Jorge, and the other 458 individuals held in the institution under inhuman and degrading conditions presented a grave and urgent risk to their lives. Based upon the egregious and irreparable nature of the human rights violations encountered, petitioners requested the Commission's immediate intervention to protect the lives and the physical, mental, and moral integrity of all those detained in the institution. Through a review of medical records, interviews, and video and photographic evidence, MDRI investigators documented clear violations of the rights to life, humane treatment, liberty and 
freedom from arbitrary or prolonged detention, as well as violations of the rights of the child, the right to equality before the law, and the right to a fair trial and due process guarantees.

\section{Violation of the Right to Equal Protection and Nondiscrimination Principles}

Petitioners argued that Paraguay's treatment of individuals detained in the institution represented grave and urgent violations of international human rights law ensuring equality before the law and anti-discrimination. Articles 1.1 and 24 of the American Convention on Human Rights (American Convention) ${ }^{3}$ contain anti-discrimination clauses and provide the right to equal protection, as does Article 2 of the Convention on the Rights of the Child (CRC). ${ }^{4}$ Further, Principle 8.1 of the United Nations' Principles for the Protection of Persons with Mental Illness and for the Improvement of Mental Health Care (MI Principles) (3) establishes the right of every consumer of mental health services to receive health and social care suitable to his or her needs at standards identical to the care received by other ill persons, as well as the right to live and work in the community. ${ }^{5}$

\section{Violation of the Right to Community Integration}

Petitioners also argued that Paraguay's obligations of nondiscrimination be examined under the Inter-American Convention on the Elimination of all Forms of Discrimination against Persons with Disabilities (Inter-American Disability Convention) ${ }^{6}$ whose very purpose is to "prevent and eliminate all forms of discrimination against persons with disabilities and to promote their full integration into society." Here, discrimination against people with disabilities is defined as "any distinction, restriction, or exclusion based on disability" having "the effect or objective of impairing or nullifying the

\footnotetext{
Organization of American States, American Convention on Human Rights, arts. 1.1, 24, Nov. 22, 1969, 1144 UNTS 123, OASTS No. 36, at 1, OEA/Ser.L/V/II.23 doc. Rev. 2, 9 ILM 673 (1970), entered into force July 18, 1978.

4 United Nations General Assembly Resolution, Convention on the Rights of the Child, art. 23.1, GA res. 44/25, annex, 44 UN GAOR Suppl. (No. 49) at 167, Doc. A/44/49 (1989), entered into force Sept. 2, 1990.

5 United Nations General Assembly Resolution, Principles for the Protection of Persons with Mental Illness and for the Improvement of Mental Health Care, GA Res. 119, UN GAOR, 46th Sess. No. 49, Annex, pp. 188-92, U.N. Doc. A/ 46/ 49. 1991.

6 Inter-American Convention on the Elimination of all Forms of Discrimination against Persons with Disabilities. Guatemala City, Guatemala. Adopted June 7, 1999, entered into force Sept. 14, 2001.
}

recognition, enjoyment, or exercise [...] of [...] human rights and fundamental freedoms." States Parties to the Inter-American Disability Convention commit to facilitating or promoting "the independence, self-sufficiency, and total integration into society of persons with disabilities, under conditions of equality."

In the institution, poor conditions and the lack of treatment negated the promotion of the individual's full integration into society. Detention within the facility undermined the mental health of patients and limited opportunities for future community integration. The absence of any identifiable active treatment, lack of treatment plans and discharge plans doomed patients to a subhuman existence in conditions that assaulted their dignity. Not only was detention under these conditions unsuitable for the needs of any individual, much less an individual perceived to have a mental disability, but moreover, these conditions did not represent care standards identical to those received by other ill persons in the country. Taken together, petitioners reasoned, the improper segregation from society and poor conditions in the facility represented discriminatory treatment against people with mental disabilities.

\section{Violations of the Right to Humane Treatment}

Petitioners also argued that Paraguay's confinement of people in the institution presented an urgent risk of grave and irreparable harm to their right to be free from cruel, inhuman and degrading treatment. Article 5 of the American Convention provides that "no one shall be subjected to torture or to cruel, inhuman, or degrading punishment or treatment," and that everyone deprived of liberty "shall be treated with respect for the inherent dignity of the human person." In examining the circumstances of Víctor Rosario Congo's detention, ${ }^{7}$ the Commission found that the Ecuadorian State violated Article 5 by placing Congo in an isolation cell and denying him proper medical attention. The Commission stated that, as Congo had a mental illness, he was in "a particularly vulnerable position," making the State's violation of his right to physical integrity even more egregious. Those detained in Paraguay's institution were determined to be in a similarly a vulnerable position, making the threats to their physical integrity particularly serious. This seriousness was further compounded in the case of

\footnotetext{
7 Organization of American States, Inter-Am Com HR, Case 11.427, Report 63/99, Victor Rosario Congo (Ecuador), para. 67, in Annual Report of the Inter-American Commission on Human Rights 1998, OEA/Ser.L/V/II.102, doc. 6 rev. 1999.
} 
Julio and Jorge given their status as minors. In some cases, petitioners argued, such conditions may rise to the level of torture.

\section{Violations of the Right to Liberty}

Further, petitioners argued that Paraguay's ongoing, unreviewed detentions of Julio and Jorge represented grave and urgent violations of the right to liberty, protected by Article 7 of the American Convention. Under Article 7, the right to liberty entails the exercise of physical freedom, which includes the right to be free from institutionalization. Although this right is not absolute, it permits restrictions of an individual's liberty only in accordance with procedures established by law. As recognized in the case of Congo noted above, the MI Principles provides a guide to the Convention's requirements for people with mental disabilities. The MI Principles set forth both substantive standards and due process protections against the arbitrary deprivation of liberty. Under MI Principle 17, admissions must be reviewed by independent and impartial review bodies "at reasonable intervals as specified by domestic law." This guarantee parallels that of Article 7 of the American Convention, which the Commission has found to have been violated where domestic procedures fail to provide for detention reviews at reasonable intervals.

\section{Violations of the Rights of the Child}

Additionally, petitioners argued that Paraguay's treatment of Julio, age 17, Jorge, age 18, and other children detained at the hospital represented grave and urgent violations of their right to special protections as children, afforded by Article 19 of the American Convention. Petitioners maintained that Paraguay had engaged in a number of flagrant violations of the Rights of the Child, particularly when the American Convention is read in conjunction with the CRC. Article 19 of the CRC establishes a State's affirmative obligation to protect children from "physical or mental violence, injury or abuse, neglect or negligent treatment, maltreatment or exploitation, including sexual abuse [...]." These obligations are heightened when a child is under State custody; under such circumstances, the State becomes directly responsible for the health and wellbeing of the child. Article 23 of the CRC specifically addresses the rights of children with disabilities, recognizing that they "should enjoy a full and decent life, in conditions which ensure dignity, promote self-reliance and facilitate the child's active participation in the community." Children with dis- abilities have a right to "special care" and assistance to ensure their effective access to "education, training, health care services, rehabilitation services, preparation for employment and recreation opportunities in a manner conducive to the child's achieving the fullest possible social integration and individual development [...]." Article 20.1 maintains that States should ensure "alternative care" for a child deprived of a family environment. This care could include adoption, placement with a foster family, or, if necessary, placement in a facility suitable for the care of children.

Petitioners argued that the institution should not be responsible for the care of children, as it had no experience in safeguarding the rights of children and no one who could speak to the best interests of the child. Contrary to being an adequate facility for the protection of the child, petitioners argued, the institution did not conform to minimum standards of health and safety. The hospital's staffing structure was dangerously insufficient, preventing active treatment and almost assuring abuse and neglect. Furthermore, children detained in the institution lived in wards with an adult population, of special concern due to the high risk of abuse.

\section{Results of the Precautionary Measures Petition}

In response to their petition, the Commission approved petitioner's request to adopt immediate measures to protect the lives and physical, mental, and moral integrity of people detained in a psychiatric institution. In its decision, the Commission called for Paraguay to comply with the following recommendations: 1) adopt all necessary measures to protect the lives, health, and the physical, mental, and moral integrity of the 460 people detained in the institution, with special attention to the situation of women and children; 2) adopt necessary measures to improve hygiene in the hospital; and 3) restrict the use of isolation cells to situations and circumstances that follow international protocols and safeguards.

MDRI brought the issue to worldwide attention by providing documentary evidence, including video footage to CNN en Español on a follow-up story, and streaming video taken during the October 2003 investigation and disseminated on the MDRI website. After this publicity, Paraguay's President and Minister of Health personally visited the hospital, fired the hospital's director, and created a commission to investigate abuses.

Since December 2003, petitioners have worked through the Commission both to address the institution's life-threatening conditions, but also to ensure that Paraguay develops a system of community- 
based mental health and social services that will guard against the repetition of such abuses in the future. In February 2005, after 14 months of sustained pressure and advocacy, petitioners signed a groundbreaking accord with the Paraguayan government. This accord requires the State to develop a plan for deinstitutionalization and the creation of community-based mental health services, and requires guarantees by Paraguay's President and Minister of Health to fund the plan. As part of the plan, Paraguay has committed to undertake a fullscale restructuring of its mental health services with the technical assistance of MDRI and Pan American Health Organization (PAHO). Such a restructuring calls for a decrease of a least $70 \%$ in the hospital's current population, and for expansion and strengthening of community-based mental health services and supports.

\section{AFTERMATH OF THE PRECAUTIONARY MEASURES DECISION: IMPLICATIONS FOR THE REGION}

The Pan American Health Organization (PAHO) has been instrumental in calling for dramatic, substantive, and sustained change in mental health services throughout the Americas. From the Declaration of Caracas in 1990 (4) to the most recent Montreal Declaration on Intellectual Disabilities in 2004 (5), PAHO has been one of the driving forces in the hemisphere, encouraging respect for and the enforcement of the rights of people with mental disabilities throughout the Region. Although the results in Paraguay are impressive and illustrate how focused advocacy and resources can bring substantial change in limited time, Paraguay is just one of many countries where the most fundamental rights of people with mental disabilities are violated on a daily, ongoing basis.

MDRI has documented these violations in a series of reports that analyze national law and international human rights principles in the context of the abuses encountered. In other countries of the Region, including Argentina, ${ }^{8}$ Mexico (6), Peru (7), and Uruguay (8), MDRI has uncovered systematic abuses of the fundamental rights of people with mental disabilities. In each country, MDRI has proposed concrete reforms that countries can undertake, in several instances at no cost or low cost, to develop services that are respectful of the rights guaranteed to every human being through jus

\footnotetext{
8 Mental Disability Rights International (MDRI) \& Human Rights Watch. Human Rights \& Mental Health in Argentina. In preparation, 2005.
}

cogens, i.e., internationally accepted human rights principles.

\section{CONCLUSION}

The substantial changes in mental health practice and policy achieved in Paraguay through this sustained advocacy evidences one of the foremost successes of the use of precautionary measures in the inter-American human rights system. Since December 2003, the Paraguayan government has taken significant steps to address life-threatening conditions in its Neuro-Psychiatric Hospital and to reintegrate people with mental disabilities into community life. In February 2005, Jorge-one of the boys detained in a feces-filled isolation cell just 14 months before-was moved to a group home in the community. Jorge now dresses and feeds himself, and is developing trusting and caring relationships with other human beings.

These changes illustrate the influence that the inter-American human rights system can have in an untested and widely overlooked area of human rights. As MDRI has documented in other countries of the Americas, the pattern of abuses against people with mental disabilities in Paraguay is similar throughout the Region. Although the detention of boys naked in tiny isolation cells is more extreme than conditions in some other countries, the improper and unnecessary detention of individuals in degrading conditions is nonetheless commonplace. The use of precautionary measures to bring about rapid change to stop life-threatening abuses in institutional settings establishes the importance of the American Convention in protecting thousands of individuals detained in similar circumstances.

As this article goes to press, MDRI, CEJIL, and PAHO are providing technical assistance for and monitoring of the implementation of this historic accord. If reforms continue in Paraguay as planned, this accord may herald a new age of mental health services in South America, respectful of the rights of people with mental disabilities so that they can become self-determined advocates of their own lives and active participants in helping shape the policies that affect them.

Acknowledgments. The author would like to recognize Tara J. Melish, former Staff Attorney at CEJIL, for her diligence in helping draft the legal petitions in this case. Funding for MDRI's work in Paraguay has been provided by the Morton \& Jane Blaustein Foundation and the Ford Foundation through a New Voices Fellowship with the Academy for Educational Development. 


\section{SINOPSIS}

\section{Los derechos humanos y la exclaustración: un triunfo para el continente americano}

El 17 de diciembre de 2003, en una decisión sin precedente, la Comisión Interamericana de Derechos Humanos pidió medidas urgentes de auxilio para proteger la vida y salud de 460 personas que estaban detenidas en el hospital neuropsiquiátrico estatal del Paraguay. Por primera vez la Comisión convocó a la toma inmediata de medidas críticas para combatir una serie de abusos que se venian cometiendo en una institución psiquiátrica. La entidad conocida por Mental Disability Rights International (MDRI, o Agencia Internacional para los Derechos de Personas con Discapacidad Mental) y el Center for Justice and International Law (CEJIL, o
Centro de Justicia y Derecho Internacional) intercedieron ante la Comisión Interamericana a favor de dos niños, Julio y Jorge, que por más de cuatro años habían estado encerrados en celdas de dos metros cuadrados, sin acceso a un baño, así como a favor de otras 458 personas recluidas en la institución en condiciones igualmente inhumanas y denigrantes. Desde diciembre de 2003, la MDRI y el CEJIL, junto con la Organización Panamericana de la Salud, han venido luchando por conducto de la Comisión para lograr cambios fundamentales no solamente en las condiciones imperantes y en el tratamiento de las personas recluidas en el hospital, sino también en la estructura de los servicios de salud mental en el Paraguay.

Palabras clave: derechos humanos, deinstitucionalización, salud mental, hospitales psiquiátricos, Paraguay.

\section{REFERENCES}

1. Hillman AA. Protecting mental disability rights: a success story in the InterAmerican Human Rights System. Human Rights Brief (American University, Washington College of Law). 2005;12(3): 25-8.

2. True M. Introduction to active treatment. Available from: http://www.ilresources. com/ACTreat1NR.htm. Accessed $23 \mathrm{Au}-$ gust 2005.

3. Rosenthal E, Rubenstein, LS. International human rights advocacy under the principles for the protection of persons with mental illness. Int J Law Psychiatry. 1993:257-73.

4. Pan American Health Organization. Declaration of Caracas. In: Jiménez R, ed. Los derechos humanos de las personas con discapacidad. San José, Costa Rica: Instituto Interamericano de Derechos $\mathrm{Hu}$ manos; 1996.

5. Pan American Health Organization. The Montreal Declaration on Intellectual Disabilities. 2004. Available from: http:// www.mdri.org/pdf/montrealdeclaration. pdf. Accessed 11 April 2005.
6. Mental Disability Rights International. Human rights \& mental health: Mexico. Washington, D.C.: MDRI; 2000.

7. Mental Disability Rights International, Association for Human Rights (APRODEH). Human rights and mental health in Peru. Lima, Peru: MDRI; 2004.

8. Mental Disability Rights International. Human rights and mental health: Uruguay. 1995. Available from: http://www. mdri.org. Accessed 11 April 2005.

For all the people confined in psychiatric institutions against their will, for all the people confined in group homes and congregate living facilities, for all the people confined by the internal walls of forced drugging, for all the people confined by the lost memories and broken brains of electroshock, I say: We will not wait! Our struggle is being fought today, on many fronts, by many brave people, who want nothing more than the chance to live our potentials, to take chances, to succeed, to fail, to try, to have opportunities, to make mistakes, to achieve, to change our minds, to be foolish, to pursue our dreams.

Judi Chamberlin, U.S. activist and author of On Our Own: Patient-Controlled Alternatives to the Mental Health System 